\title{
Using Science Fiction Films to Advance Critical Literacies for EFL Students in China
}

\author{
Shuyuan Liu* \\ Rossier School of Education, University of Southern California, Los Angeles, CA, USA \\ Corresponding author: Shuyuan Liu, E-mail: shuyuanlau@gmail.com
}

\section{ARTICLE INFO}

Article history

Received: March 02, 2019

Accepted: July 20, 2019

Published: July 31, 2019

Volume: 7 Issue: 3

Conflicts of interest: None

Funding: None

\begin{abstract}
As a unique literary genre, science fiction can serve as a motivating text to develop students' critical analytical skills and to promote critical thinking about new technology and its societal controversies under proper guidance. In the field of English as Foreign Language (EFL) learning, using science fiction films in the classroom affords EFL learners new language-learning experiences. This paper explains how films, as a multimodal resource in EFL classes, can enrich students' multiliteracies - specifically how the science fiction genre can develop students' critical literacies under careful meaning-making curriculum design. A preliminary study, taking 30 students in a foreign language high school in China, is reported in this paper. Findings reveal that carefully selected science fiction films such as I am Legend and Blade Runner can serve as pivotal sources for developing EFL learners' literacy under the multiliteracies pedagogy. Such films can also connect students with Western ideology to reinforce their identity as participants in globalization. This study further suggests that key points in successful design of the course in an EFL classroom include posing critical questions to promote critical thinking and actively analyzing multimodal texts to uncover underlying meanings in source material.
\end{abstract}

Key words: Multiliteracies, Multimodality, Critical literacies, Science fiction film, English as Foreign Language

\section{INTRODUCTION}

Teaching literacy through science fiction films offers an alternative to traditional literacy pedagogy, which has been limited to reading and writing modalities and has ignored other modes of meaning that could influence traditional literacy (New London Group, 1996). Several studies have examined the use of film to promote literacy (Ahn, 2014; Barnett \& Kafka, 2007; Wu, 2016); however, science fiction films, as a unique film genre, have never been systematically incorporated into English as foreign language (EFL) classrooms to help students acquire either visual literacy or critical literacy. Intellectually substantive science fiction films, such as I am Legend (Goldsman, Lassiter, Heyman, \& Morits, 2007) and Blade Runner (Deeley, 1982; see Table 1 for similar examples), that foreground totalitarianism, science and technology ethics, Western ideologies, and globalization provide EFL learners opportunities to participate in discussions as global citizens. Such films' multimodalities and engaging content may enrich EFL pedagogy in China's elite foreign language high schools, namely by deepening students' reading engagement and promoting critical literacy skills. For EFL learners in China, engagement with global issues (rather than mere language learning) can enhance critical thinking skills, which are often lacking among Chinese students compared to their Western counterparts (Guo, 2013; Guo \& O’Sullivan, 2012; Hu, 2017).
This paper advocates for the use of science fiction films to facilitate English learning by implementing a multiliteracy pedagogy that enriches learners' traditional literacy. Two science fiction films, I am Legend and Blade Runner, are presented and analyzed as possible teaching resources that can facilitate critical literacies in EFL classrooms in China. After reporting on a study that includes these films in an EFL high school class in China, this paper concludes by examining how carefully selected science fiction films can be used to develop students' multiliteracies.

\section{LITERATURE REVIEW}

\section{Films and Multiliteracies}

With the emergence of new modes of expression through media, educators have begun to rethink what constitutes literacy beyond reading and writing ability (Cope \& Kalantzis, 2009; New London Group, 1996). The term multiliteracies encompasses the ability to understand and use all forms of communication (i.e., written, aural, visual, linguistic, and digital) across a multitude of contexts and adapt these forms for personal and social development (New London Group, 1996). This definition shifts from an individual focus to community engagement, most often online or through other technological modalities. Within the context of multiliteracy, teaching methods seek to liberate literacy from the traditional 
Table 1. Examples of intellectually substantive science fiction films

\begin{tabular}{|c|c|c|c|c|}
\hline Title & Director & Year & Distributor & Based on \\
\hline $\begin{array}{l}\text { 2001: A Space } \\
\text { Odyssey }\end{array}$ & $\begin{array}{l}\text { Stanley } \\
\text { Kubrick }\end{array}$ & 1968 & Metro-Goldwyn-Mayer & \\
\hline $\begin{array}{l}\text { The BiCentennial } \\
\text { Man }\end{array}$ & $\begin{array}{l}\text { Chris } \\
\text { Columbus }\end{array}$ & 1999 & Buena Vista Pictures Distribution & $\begin{array}{l}\text { The Positronic Man by Isaac } \\
\text { Asimov \& Robert Silverberg }\end{array}$ \\
\hline Blade Runner & Ridley Scott & 1982 & Warner Bros. & $\begin{array}{l}\text { Do Androids Dream of Electric } \\
\text { Sheep? by Philip K. Dick }\end{array}$ \\
\hline Ex Machina & Alex Garland & 2015 & A24 (U.S.) Universal Pictures (International) & \\
\hline $\begin{array}{l}\text { Edge of } \\
\text { Tomorrow }\end{array}$ & Doug Liman & 2014 & Warner Bros. Pictures & $\begin{array}{l}\text { All You Need Is Kill by Hiroshi } \\
\text { Sakurazaka }\end{array}$ \\
\hline I Am Legend & $\begin{array}{l}\text { Francis } \\
\text { Lawrence }\end{array}$ & 2007 & $\begin{array}{l}\text { Warner Bros. Pictures, Roadshow } \\
\text { Entertainment (AUS \& N.Z.) }\end{array}$ & $\begin{array}{l}\text { I Am Legend by Richard } \\
\text { Matheson }\end{array}$ \\
\hline I, Robot & Alex Proyas & 2004 & $20^{\text {th }}$ Century Fox & I, Robot by Isaac Asimov \\
\hline The Island & Michael Bay & 2005 & DreamWorks Warner Bros & \\
\hline The Road & John Hillcoat & 2009 & Dimension Films & The Road by Cormac McCarthy \\
\hline
\end{tabular}

shackles of reading and writing to expand learners' literacy to include additional communication channels (Gee, 2012). Therefore, a relevant instructional framework should include the following components (New London Group, 1996): (a) situated practice that relates content to students' backgrounds and experiences; (b) overt instruction using metalanguage to describe the process and design of learning; (c) critical framing, which promotes understanding of the social, cultural, and historical backgrounds of knowledge; and (d) transformed practice, which transforms situated practice and theory into action. As schools begin to incorporate new media technologies for teaching and as multimodal practices pervade modern society, multiliteracies pedagogy should reshape teaching methods in existing curricula with proper scaffolding.

Films can reflect modern learners' participation in meaning-making in the information technology era, presenting an intriguing way to enrich language instruction. Wu (2016) mentioned using filmic media as a medium to bring foreign culture and its value into the classroom and to develop students' cross-cultural competence. Bruti (2016) demonstrated that using film clips in the foreign language classroom can help students comprehend the pragmatic features within a conversation interaction. Despite the prospects of film-based teaching for young generations, teachers should adopt a critical eye in light of the transparency problem (Jenkins, Clinton, Purushotma, Robison, \& Weigel, 2006); that is, youth may struggle to perceive the effects clearly of film content on their world views. Ethics poses another challenge in that youth may identify moral dilemmas in film. Teachers should therefore pay close attention to what and how they teach so as to guide young learners to acquire social skills and cultural competences through teaching film. As film watching is not simply classroom entertainment, teachers must be able to modify and refine this strategy for efficient implementation, such as by using prompts and leading questions to help students understand key concepts (Ahn, 2014). Within the multiliteracies framework, teachers should also develop a metalanguage to analyze different modes of meaning-making in film (Cope \& Kalantzis as cited in Cloonan, 2011). Examples include representational modes (i.e., who and what is being represented in the text?), contextual modes (i.e., what does this text mean in a sociocultural context?), and ideological modes (i.e., who is the target audience?). Only under such guidance can learners fully benefit from film-based teaching in a language classroom.

Although new media literacies derived from multiliteracies can supplement traditional textual literacy (New London Group, 1996), the latter remains crucial. Jenkins et al. (2006) argued that new media literacy should not be considered a new part of the school curriculum but rather a refinement of current teaching methods. Film-based teaching has the potential to incorporate traditional and new literacies, such that using films compensates for the difficulties that students have in comprehending textual meanings. Therefore, film serves as an auxiliary tool to prepare students for textual materials such as novels based on films. As some traditional texts may be too challenging for EFL learners, teachers could use films as a starting point before digging more deeply into linguistic and social issues.

\section{Critical Literacy and Science Fiction}

Educators have discussed critical literacy in language pedagogies, referring to developing students' ability to examine discrimination embedded in a text or media due to the presenter's social and political influence (Lewison, Flint, \& Sluys, 2002); however, this concept holds more promise in the multiliteracy era. Gounari (2009) re-examined critical literacy within the framework of new technologies, emphasizing visual space as an emancipatory and powerful tool. Ahn (2014) pointed out that even though film watching is a common social activity in today's digitalized world, film comprehension cannot necessarily occur without guidance. She further proposed that watching films in the classroom can effectively encourage students to gain critical literacy when films' genres and themes are carefully selected, and the target viewers and purposes are analyzed in the context of new-literacy pedagogy.

Science fiction, as a literary genre, often involves an imagined future characterized by drastic advances in tech- 
nology and science, time travel, and extraterrestrial life. However, science fiction is a nebulous term with various subgenres. In this paper, I adopt Isaac Asimov's definition of science fiction (1975) as a "branch of literature which deals with the reaction of human beings to changes in science and technology" (p. 62). Based on this definition, I focus on science fiction in which human beings cope with earthly technological innovations rather than those from outer space. An early example of such literature is Shelley's Frankenstein (1818), where Dr. Frankenstein creates a monster based on a scientific experiment. The rising scenario of new technology and its current controversies thus requires critical analytical skills for better comprehension (Pile \& Thrift, 1995, as cited in Damarin, 2004). And such themes inspire critical reflection on humans' future relationship with technology amidst rapid technological advancement, providing interesting topics to promote students' critical thinking skills.

In addition to presenting an imagined future, science fiction films can also offer valuable reflections (from the writer and general audience) on a nation's ideology, history, culture, and society. For instance, in 2001: A Space Odyssey, Kubrick (1968) designed apes in a prehistoric time to have the same facial expressions when looking at a black stone as future astronauts looking at the same stone in outer space. When watching this scene, viewers may consider that an alternative way of perceiving the future of technology is to examine the past, which might also be what the director had planned. Because such themes are universal to any viewer, a discussion is relevant to speakers of any language. Therefore, in EFL settings in China, students may become interested in aspects of English culture, history, ways of thinking, and Western social and ideological features by comparing these characteristics with their own, which represents a path to comprehension and participation in modern globalization.

Science fiction films such as I am Legend and Blade Runner present another practical point for contemplation: attitudes towards species that are just as intelligent as humans (if not more), such as in the relationships between humans and creatures with artificial intelligence. Thus, implementing science fiction films in the classroom contextualizes the English language to facilitate learners' language use. Though fictional, the relationship between man and man-made creatures may not be as distant in authentic life, as it may also be analogous to that between man and machine, with which people are familiar today. Teachers can ask questions to encourage students to consider the similarities and differences between man and man-made creatures in relation to the intrinsic features of humanness and then bring up a discussion on man's attitude towards technology. For example, in Blade Runner, the Replicant looks and functions similarly to (or better than) humans in strength and intelligence; thus, humans in the film feel threatened. Such questions and themes can broaden the perspectives of EFL learners in China and are universal in a globalized society.

Using science fiction films in the classroom can also enrich students' critical visual literacy. Barnett and Kafka (2007) suggested that critical analysis of visual media in science fiction films should be developed using proper pedagogical approaches to assist students in acquiring critical visual literacy. Teachers can guide students by posing critical questions similar to those raised by Wallace (2001), such as "What is the topic of the film and why is it important?" and "What audience does this film target?" For example, I am Legend has two endings, each of which is underpinned by different ideologies. Teachers can thus ask questions such as "Why do you think there are two versions of the ending?" and "Who are the respective target audiences?" These questions can help students understand why a story is written for certain viewers and how writers achieve their purpose of reaching these viewers, both of which are prime considerations in critical literacy.

\section{METHOD}

\section{The Course: I am Legend and Blade Runner in an EFL Classroom}

Lawrence's I am Legend (2007) takes place in New York City after a virus, originally created to cure cancer, has killed most of mankind and turned a small proportion into hostile mutants called Darkseekers. At the end, close to developing a cure for the virus from a Darkseeker's body, Neville (one of the few human survivors) gives up by returning the female Darkseeker's body. Similarly, Scotte's Blade Runner (1982) tells the story of future human beings and Replicants, who are bio-engineered to be identical to real humans. When a fugitive group of Replicants escapes, police officer Rick Deckard is sent to hunt them, arousing suspicion that he is a Replicant as well. In both stories, intelligent creatures are born out of advances in technology and medicine.

Such contents may be challenging to comprehend or unfamiliar to EFL learners; thus, I designed a motivation activity intended to capture students' attention around predicting the future. By presenting two illustrations related to the books 1984 and Brave New World (see Figures 1 and 2 ), which depict dystopian societies, students can discover that a future with technological and medical advances is not

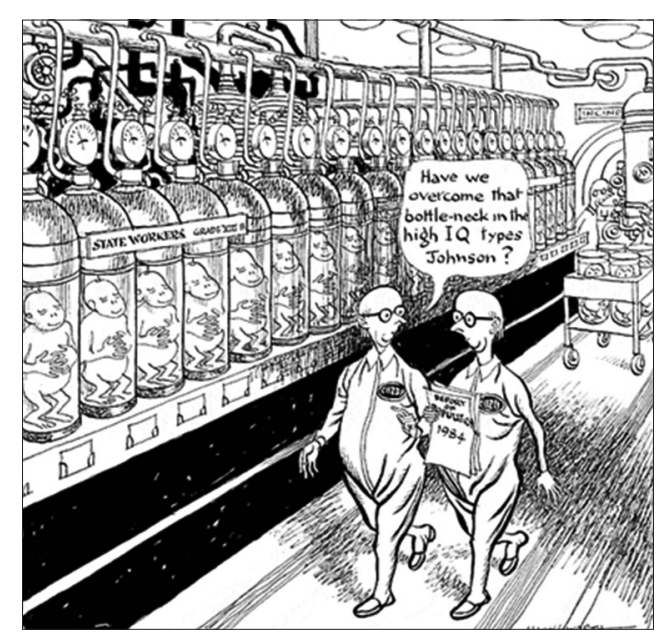

Figure 1. 1984 Cartoon illustration. Reprinted from George Orwell To Get A Blog of Guest of a Guest, by S. Stuyvesant, 2008, Retrieved from http://cairsweb.llgc.org.uk/images/ ILW1/ILW1611.gif 


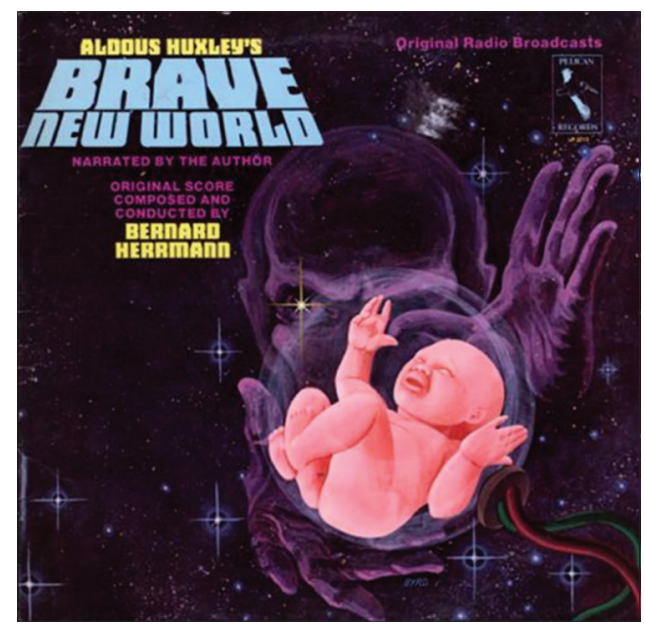

Figure 2. Brave New World album cover illustration. Reprinted from Brave New World of LP Cover Art, by L. Byrd, 2013, Retrieved from http://farm6.static.flickr. com/5285/5251182494_eb76e0eb94_b.jpg

always bright. Moreover, presented with such showcased images, students can develop early visual literacy contextually through the illustrations' rich visual and linguistic information.

The key to successful implementation of the two films, which could otherwise be seen simply as entertainment, is critical framing (New London Group, 1996) that initiates critical thinking. After presenting pivotal moments from four pre-selected segments of I am Legend, I posed questions that focused on the film's details (see Appendix), such as mentions of God, the meaning of the butterfly that the Darkseeker drew on the glass wall, and the reasons for having two endings (in the alternate ending, the Darkseekers become extinct and the humans survive). Close examination of these questions in the classroom can lead to other topics of interest, such as what man's reaction will be towards intelligent creatures and whether these creatures are in competition with man. The class can also discuss long-term effects of medical advances. Challenging though consideration of these notions is, they nonetheless may apply in the near future. Moreover, the two endings can trigger thinking by learners about target audiences and prompt reflection that the alternative ending might compromise a heroic Hollywood film that caters to a large audience; such an audience may be dissatisfied with an ending in which human superiority is taken away by the threatening Darkseekers.

The questions (Appendix) about Blade Runner can also attract student attention to visual and aural representations, such as the film's general color tone and soundtrack; the eye, the owl, and the dove; and the protagonist's speech about life and death. The goal of these questions is to enable students to focus on the ethics of science and technology, which may be starkly different from present morality. Investigating questions about morality in technology can lead to discussions of current news and topics, such as AlphaGo beating the top human player in a chess championship, cloning and genetic technologies, and emerging developments in the field of artificial intelligence. These are all subjects with which most
EFL learners in China's elite foreign language schools are familiar.

The class concluded with establishing connections between the illustrations presented at the beginning and the two films themselves. By presenting the analogy that these works provide perspectives on humans' future in the context of scientific and technological advances, I gave roots to the idea of a "dystopia," a dehumanized future world full of fear that represents a significant lesson in modern Western thinking. Dystopian novels such as 1984 and Brave New World were recommended as out-of-class readings. In this way, multimodal texts (i.e., book covers and films) collectively served to introduce paper-based texts by arousing students' interest early in the instructional sequence.

\section{Setting and Participants}

The school setting for this instructional intervention was a dedicated foreign language high school in China where students' average English proficiency is higher than that in general high schools. The 60-minute class consisted of sophomores and had about 30 students. Most students were academically competitive in subjects like math, science, art, and English. The subject class was selected because such students are usually considered future leaders of China and comprise an elite group (Norton \& Gao, 2008); these students may thus be more willing to accept new ideas and pedagogies.

\section{Data Collection}

This study involved a qualitative method; data were collected from classroom observation notes, students' in-class oral assessments, and their post-class reflective reports. All classroom activities, along with several brief conversations immediately after class dismissal, were recorded and transcribed for analysis. Classroom observation notes were drafted after the completion of the lesson, namely by reviewing video recordings of the class process. The purpose of classroom observations was threefold. First, the observations were reviewed to identify the extent to which students participated in each activity phase (i.e., motivation activity, input activity, output activity, culmination, and extension; see Appendix). Observation notes focused on phases that yielded better results and on phases in which students appeared reluctant to participate actively. Second, classroom observations were recorded to monitor students' engagement during group discussion and collect potential group responses that may be related to critical analytical skills and critical thinking. Third, observations were used to determine the extent to which students responded to the aforementioned specifically designed steps (i.e., students' level of attention to visual and aural representations in the films; the seven critically framed questions in the Appendix regarding students' comprehension of pivotal moments in pre-selected film segments; and potential discussion of societal topics initiated by viewing the film clips).

At the end of the class, students completed brief oral assessments to share their thoughts on humans' future compared 
to what they thought at the beginning of class. A 5-minute group discussion was held first. Volunteered answers were encouraged, but students were also called upon to speak to the class. Six students responded, either voluntarily or by request. The author called upon two students she identified as lower achievers, two who were moderate achievers, and two who were higher achievers. Students' answers were limited to within 2 minutes each, and all responses were recorded and transcribed for analysis.

The third type of data came from students' reflective reports after class. Post-class reports were optional; accompanying data were intended to supplement findings generated from classroom observation notes and the in-class oral assessment. The reflective report could include a) any elaborated thoughts on the contents of in-class discussion; b) thoughts on one or more of the after-class recommended readings (i.e., the dystopian novels Nineteen Eighty-four, Brave New World, We, and an extension reading with the title Amusing Ourselves to Death); and c) students' own experiences with technological advances they had initially been reluctant to use. All responses were analyzed for potential findings related to improvements in students' critical literacy.

\section{FINDINGSANDANALYSIS: TEACHINGWITH IAM LEGEND AND BLADE RUNNER}

For input-phase questions, students were called upon when they volunteered to answer. In the output phase, where four discussion groups were formed to examine the four questions respectively, each group was required to vote for one speaker to present the group's collective answers. Among these types of discussion and brainstorming activities, students tended to be more willing to participate in group discussion near the end of class. Moreover, group discussion elicited wider perspectives and topics than classroom brainstorming and presentation; subjects ranged from DNA testing, genetic engineering, and environmental solutions to cancer cures. One group even drew an analogy between I am Legend and the Chinese Wuxia (i.e., martial heroes) novel The Smiling, Proud Wanderer. These students pointed out that at first glance, protagonist Robert Neville appeared to be a superhero who could save all humans' lives.

Students noticed the dark lighting in the film I am Legend, indicating that the future described therein was somewhat negative. They began focusing on the double-edged sword of advances in medical technology while considering the Darkseekers a new species threatening the domination of humans. The film helped students see interrelationships among the various modalities in meaning making and thus shaped students' comprehension of the subsequent film. In Blade Runner, students reported that the tone seemed even darker than I am Legend, with rain and smog present throughout the movie. This film presented an entirely negative perspective on human life in the future. Some EFL students may have had difficulty understanding some language used in the film, possibly because 1) the film was produced in 1982 (thus, the language may be outdated); and 2) there could be linguistic and cultural differences between EFL students and the presumed target audience of native English speakers. Even so, all students recognized the basic tone the director wanted to express via the chosen visual and aural modalities.

At the end of I am Legend, the alternate ending in which humans survived was played on screen, and the class voted on which they preferred. Students liked the original ending better than the alternate one, stating that the male Darkseeker and its followers were not trying to kill human beings but only requiring Neville to return the female Darkseeker. One student mentioned that the alternate ending may be intended for audience members who were reluctant to see human extinction and preferred the superhero films to which they may be more accustomed. This student's reply and my follow-up question inspired some students to contemplate the director's target audience for each ending. Ongoing discussion was paused due to limited class time.

In the oral assessment phase near the end of class, many students shared that this class marked their first exposure to film-based questions and that the discussions had piqued their interest in issues concerning technology, humans' future, societal problems, and globalization. The film and ensuing conversation also broadened their knowledge and critical thinking skills. One student representative of his group concluded that "the prediction of the future could not be assumed as binary [i.e., either bright or dark], but we need to focus more on the technology that seems absolutely beneficial to us and take a critical view of it."

Though some students appeared bored in certain activity phases, most expressed interest before class ended, either by speaking out directly or actively engaging in subsequent activities. For example, one student remarked immediately after class, "I was not sure if this [would be] useful to pass the test, but I [started] to think that the topics [were] important and necessary to consider." The student realized there were new topics worthy of contemplation besides those introduced through reading and writing. His words indicated that his understanding of critical literacies had begun to change and that such literacies are at least as important as conventional literacy. Before class was dismissed, nearly all students expressed a desire to finish watching at least one of the two films. As students became fully immersed in the films, many expressed interest in searching for other science fiction films and those related to technology, Western ideology, and globalization. Their enthusiasm inspired me when planning subsequent classes to introduce another set of films previewing possible human futures, such as John Hillcoat's The Road and Roland Emmerich's 2012.

Three post-class reflective reports were submitted. One student, who read Amusing Ourselves to Death (1985) outside of class per the curriculum recommendation, reported thinking that humans' future may be at risk-not from totalitarianism but from the "soma" people create. Another student reported thinking that the two facets could be intertwined and mutually reinforcing to some extent. Teaching through new media also enabled students to consider issues through a global lens while focusing on current events and problems. One student cited an idea from Yuvah Harrari, a best-selling author popular in China, regarding the prospect of technology-aided, long-living humans who might exist in the near future by virtue of technological and medical advances. 


\section{DISCUSSION AND IMPLICATIONS}

From the classroom observation notes, group discussion responses, oral assessments, and post-class reflective reports, teaching I am Legend and Blade Runner had a positive impact on students' literacy learning. First, students' strong engagement in group discussion indicated that literacy learning can be more effective when implemented within a participatory learning environment. Second, watching film excerpts helped students gain a clearer understanding of the basic tone of each story and its rich visual and aural modes. Thus, the multimodal nature of films compensated for students' linguistic challenges while also guiding and supporting conventional reading and writing. Teaching science fiction films in EFL settings can also advance students' critical literacy. By discussing the alternate endings of I am Legend, students reflected on questions about critical literacy, including who owns the media and for whom various forms of text are created. In terms of promoting critical literacy, these students will likely assume a critical perspective when considering future literary works and may develop independent thoughts, which are often lacking among Chinese students.

In terms of schools across the nation, EFL learners in China may often hold negative perceptions of the efficiency of critical literacy compared with conventional literacy. In general, students tend to be skeptical of critical literacy because they would prefer to learn more "useful" language knowledge. In the EFL setting where learning survival language is usually a priority (Eastman, as cited in Huang, 2011), perceptions of "useful" language are based on exams and rote memorization, which mostly focus on language skills and communicative ability with less attention to critical questioning, logical thinking, and an examination of embedded discrimination required in critical literacy. Although the subject school in this study offers advanced education in English, students expressed reluctance at developing their critical literacy; as such, the critical literacy approach might be more challenging to popularize among learners in normal schools in China.

In spite of this challenge, teaching science fiction films like I am Legend and Blade Runner had a positive impact on learners' perceptions of critical literacy. The students from the subject school were able to gradually shift their focus from traditional literacy to critical literacy. Therefore, before implementing a critical literacy approach, teachers should encourage students to realize that critical literacy is no less important to practice than literacy itself. Relatedly, instructors must incorporate carefully chosen science fiction film resources and meaning-making designs in the classroom. This presents several advantages: students can experience the power of critical questioning and group research on a new topic along with the idea of morality and future prospects in science and technology. Moreover, conventional literacy and critical literacy practice can occur simultaneously and reciprocally. The emphasis on critical film analysis in this study helped students realize that conventional literacy is subconsciously and naturally practiced while developing critical literacy. Critical awareness of multimodal texts also evoked students' motivation to self-study language skills and reflect on the sociopolitical issues brought up by the selected film contents. Such introspection in the EFL classroom should inspire students' confidence to engage as future decision makers in broader sociopolitical issues beyond the classroom.

\section{CONCLUSION}

In closing, even with the popularity of teaching through film, younger generations may have limited opportunities to examine film content critically and consider the ethical implications of new practices. Thus, one may suggest that professional guidance and pedagogy be implemented to ensure that students acquire core media literacy skills. Science fiction films are a tool through which students can obtain multiliteracies and critical literacies. When adopting a multiliteracy pedagogy and cultivating students' critical literacy, teachers should be sensitive when choosing science fiction film resources and meaning-making designs. Teachers of EFL in China should also carefully consider how traditional teaching methods can be enriched by supplementary teaching resources and methods involving film. Furthermore, students should be made aware that watching a film in class is not intended as entertainment or relaxation but rather as an alternative way to acquire multiliteracies and critical analytical skills from deliberately chosen film clips. Overall, using science fiction films such as I am Legend and Blade Runner can help EFL learners achieve skills that are critical to contributing responsibly as global citizens.

\section{REFERENCES}

Ahn, C. (2014). Zooming in on film in the English classroom. English Practice, 56(1), 49-54. Retrieved from http://bctela.ca/wp-content/uploads/2013/08/Multiple-Pathways-Diverse-Texts1.pdf

Asimov, I. (1975). How easy to see the future! Natural His-

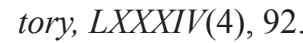

Barnett, M., \& Kafka, A. (2007). Using science fiction movie scenes to support critical analysis of science. Journal of College Science and Teaching, 36(4), 31-35.

Brown, L., Iwasaki, N., \& Lee, K. (2016). Implementing multiliteracies in the Korean classroom through visual media. In Y. Kumagai, A. López-Sanchez, \& S. Wu (Eds.), Multiliteracies in world language education (pp. 158-181). Oxon, UK: Routledge.

Bruti, S. (2016). CHAPTER 7: Teaching compliments and insults in the EFL classroom through film clips. Utrecht Studies in Language and Communication, 29, 149-170, VIII. http://dx.doi.org/10.1163/9789004323902_009

Cloonan, A. (2011). Creating multimodal metalanguage with teachers. English Teaching: Practice and Critique, 10(4), 23-40. Retrieved from https://edlinked.soe.waikato. ac.nz/research/files/etpc/files/2011v10n4art2.pdf.

Cope,B.,\&Kalantzis,M.(2009). “Multiliteracies”:Newliteracies, new learning, Pedagogies: An International Journal, 4(3), 164-195. https://doi.org/10.1080/15544800903076044.

Darmarin, S. (2004). Required reading: Feminist sci-fi and post-millennial curriculum. In J. A. Weaver, K. Anijar, \& T. Daspit (Eds.), Science fiction curriculum, cyborg 
teacher, \& youth cultures; (pp. 51-73). New York, NY: Peter Lang.

Deeley, M. (Producer), \& Scott, R. (Director). (1982). Blade Runner. [Motion picture]. United States: Warner Bros.

Gee, J. (2012). Social linguistics and literacies: Ideology in discourses ( $4^{\text {th }}$ ed.). New York, NY: Routledge.

Goldsman, A., Lassiter, J., Heyman, D., Morits, N., (Producer), \& Lawrence, F. (Director). (2007). I Am Legend. [Motion picture]. United States: Warner Bros. Pictures.

Gounari, P. (2009). Rethinking critical literacy in the new information age. Critical Inquiry in Language Studies, 6(3), 148-175. https://doi.org/10.1080/15427580903115164

Guo, L., \& O’Sullivan, M. (2012). From Laoshi to Partners in Learning: Pedagogic Conversations Across Cultures in an International Classroom. Canadian Journal of Education, 35(3), 164-179. Retrieved from https://search. proquest.com/docview/1115387100?accountid=37892

Guo, M. (2013). Developing Critical Thinking in English Class: Culture-based Knowledge and Skills. Theory and Practice in Language Studies, 3(3), 503-507. http://dx. doi.org/10.4304/tpls.3.3.503-507.

Hu, M. (2017). Teachers' Intervention in Developing English Majors' Critical Thinking When Teaching Writing in Chinese Universities. Theory and Practice in Language Studies, 7(12), 1290-1294. http://dx.doi.org/10.17507/ tpls.0712.16.

Huang, S. (2011). Reading "Further and Beyond the Text" Student Perspectives of Critical Literacy in EFL Reading and Writing. Journal of Adolescent \& Adult Literacy, 55(2), 145-154. Retrieved from https://www.jstor. org/stable/41309669.

Huxley, A. (2007). Brave new world (6 ${ }^{\text {th }}$ ed.). Toronto: Vintage Canada.

Jenkins, H., Clinton, K., Purushotma, R., Robison, A. J., \& Weigel, M. (2006). Confronting the challenges of participatory culture: Media education for the $21^{\text {st }}$ century. Chicago, IL: MacArthur Foundation. Retrieved from https://www.macfound.org/media/article pdfs/JENKINS_WHITE_PAPER.PDF.

Lewison, M., Flint, A. S., \& Van Sluys, K. (2002). Taking on critical literacy: The journey of newcomers and novices. Language Arts, 79(5), 382-392. Retrieved from https://www.researchgate.net/publication/284055039 Taking_on_critical_literacy_The_journey_of_newcomers_and_novices.

Mitchell, R., \& Myles, F. (2004). Second language learning theories. London, UK: Hodder Arnold.

New London Group. (1996). A pedagogy of multiliteracies: Designing social futures. Harvard Educational Review, 66(1), 60-92.

Norton, B., \& Gao, Y, (2008). Identity, investment, and Chinese learners of English. Journal of Asian Pacific Communication 18(1), 109-120. https://doi.org/10.1075/ japc.18.1.07nor.

Quinlisk, C. C. (2003). Media literacy in the ESL/EFL classroom: Reading images and cultural stories. TESOL Journal, 12(3), 35-40.

Shelley, M. W. (1818). Frankenstein, or, The modern Prometheus. London, UK: Lackington, Hughes, Harding, Mavor, \& Jones.

Wallace, C. (2001). Critical literacy in the second language classroom: Power and control. In B. Comber \& A. Simpson (Eds.), Negotiating critical literacies in classrooms (pp. 209-228). Mahwah, NJ: Erlbaum.

Warner C., \& Dupuy B. (2018). Moving toward multiliteracies in foreign language teaching: Past and present perspectives.and beyond. Foreign Language Annals, 51, 116-128. https://doi.org/10.1111/flan.12316.

Wu, S. (2016). Creating an effective learning environment in an advanced Chinese language course through film, poster presentations, and multiliteracies. In Y. Kumagai, A. López-Sanchez, \& S. Wu (Eds.), Multiliteracies in world language education (pp. 209-232). Oxon, UK: Routledge. 


\section{APPENDIX}

Sample Lesson Plan: Introducing Science Fiction and Teaching Future Tense to English Language Learners

\section{LESSON PLAN CONTEXT}

\section{Setting}

Foreign language high schools in China where students' average English proficiency is higher than that in general high schools. 30 students, Week 5 of 7 weeks, 60 minutes, high school Sophomore year, Science fiction.

\section{Standards}

- Students read and perceive the text materials and demonstrate an understanding of the language from varied literature;

- Students analyze, describe and explain their ideas in written and spoken presentations.

\section{Learning Objectives}

By the end of the lesson, learners will be able to:

- Become familiar with future tense grammar use;

- Develop critical literacy and critical analytical skills on thoughts about current controversies in medical and technological innovations.

\section{Learning Theory Applications}

- Constructivism learning theory indicates that people utilize current knowledge to construct new knowledge. By this theory, learning activities are designed to relate to students' own beliefs and past experience. Since everyone is making their own contribution, there is no single best or correct solution in group discussions

- Cognitive theory emphasizes that people have the ability of mentally processing the information over time. Therefore, students are encouraged to use think-aloud procedures, and to actively involve in their own learning and meaning-making activities.

- Sociocultural theory points out that language practices develop from social, cultural, and historical interactions. Learners participate in meaningful sociocultural activities while simultaneously learn from them. Students are encouraged to solve problems in groups, and are guided from teacher to discover solutions by themselves (Mitchell \& Myles, 2004).

\section{Learning Accommodations}

- Advanced English learners are encouraged to do out-ofclass recommended readings, and write short reflections regarding the topics involved in class discussions.

- Discussion groups will pair slow learners with advanced learners.

\section{Resource Accommodations}

- For classrooms with "high tech" resources, every student has access to computer where the film clips could play. Or the classroom has a computer connecting to a projector so that all students watch the film clips on the big screen;

- For classrooms with "mid tech" resources, there may be only one computer, DVD player and one small screen. Film clip watching activity could be split into two small sessions, with 15 students in each session;

- For classrooms with "low tech" resources or without any technological devices, teacher can emphasize on the introduction of the film and hand out paper-based image materials that reflect the crucial moments from the film clips.

\section{Learning Materials}

- $\quad$ Both learners and teacher: films I am legend by Akiva Goldsman (2007), Blade Runner by Ridley Scott (1982), and Aldous Huxley's (1931) novel Brave New World.

- Supplementary materials for teacher: George Orwell's (1948) Nineteen Eighty-four, We by Yevgeny Zamyatin (1921), the novel I am legend by Richard Matheson (1954), and Philip K. Dick (2005), Do androids dream of electric sheep? Mitcham. C, Encyclopedia of Science and Technology Ethics.

\section{LESSON PLAN PROCEDURES}

\section{Phase I: Motivation Activity}

- Teacher introduces today's topic about prediction of future life, and leads brainstorm activity of such topic.

- Then teacher presents illustrations from book covers of Brave New World and Nineteen Eighty-four (Figure $1 \&$ Figure 2) or similar dystopian society image, and guides students to conclude that future is not all bright in some viewpoints.

- This activity is for the purpose of practicing and reviewing future tense, as well as engaging students with the issue of future science and technology. Presenting the illustrations can assist students constructing relevant ideas and get them familiar with the topic. Time of the activity should be no more than 10 minutes.

\section{Phase II: Input (Teacher Driven) Activity}

- In this phase, teacher gives a brief introduction of the film I am legend, and then presents four pre-selected segments for approximate 10 minutes (00:02:18 - 00:03:06, $1: 14: 14-1: 15: 27,1: 19: 08-1: 23: 10,1: 27: 30-1: 30: 14)$. For "low-tech" classroom, teacher prepares paper-based image materials that reflect the pivotal moments from the four segments and can allocate more time for classroom discussion.

After watching the film segments, teacher asks questions designed specifically to concentrate on the details 
of the film, such as the mention of God, the meaning of the butterfly, and the indication of the ending.

Q1. What did Neville mean in the second segment that "God didn't do this. We did"?

Q2. In the last segment, what is your interpretation regarding the butterfly the Darkseeker drew on the glass wall?

Q3. There are actually two versions of ending. In the alternate ending, Neville refused to release the female Darkseeker, and died for protecting the vaccine. What is your understanding of the alternate ending? State which version you like and the reason.

- Teacher should direct students' attention to the visual and aural modes of the film, such as the basic colors, and how the various modalities interrelate with each other to achieve a special viewing effect.

\section{Phase III: Output (Learner Driven) Activity}

- In the third phase, teacher presents four segments from the film Blade Runner for 10 minutes (00:02:0400:04:20, 00:17:09—00:21:42, 01:22:36-01:25:53, $01: 44: 30-01: 49: 02)$. Each of the discussion groups is assigned one of the questions below, and should arrange a collective answer for class presentation.

- The four discussion questions correspond with the four segments. Teacher should guide students to focus on the visual representations, such as the eye appeared in the first segment, the owl in the second segment, and the dove in the last segment.

Q1. In the first segment, what do you think the eye stands for? How do you feel about the general tone contributing to the theme of the film, considering the colors, and the soundtrack etc.? Make comparisons to the previous film on those aspects.

Q2. In the second segment, what can be inferred from the general color of sun and the light in the testing room? How do you interpret the scene of test for Replicant?

Q3. From the dialogue between the Replicant and the maker in the third segment, can you infer an analogy between human beings and God?

Q4. How do you interpret the ending of the film? Pay special attention to the last Replicant's speech about death and life, and the police officer who spoke to the blade runner.

- The questions above are all open questions without fixed answers. The intention is to direct students to the controversies of science and technology and modern morality. In order to better comprehend the film, students are encouraged to read Philip K. Dick's novel that the film adapted from.

\section{Phase IV: Culmination}

- In the final phase, after each group's presentation on their assigned question, teacher makes an integration of the opinions and complements the ideas. A crucial point is that teacher should establish connections between the illustrations shown at the beginning and the two films. By making analogies that these works are all predictions of human future in the context of technological advancement, teacher brings in the concept of "dystopia" and can recommend dystopian novels as out-of-class readings.

- For the assessment of the first learning objective, teacher walks around the classroom at discussion time observing students' grammatical usage, and also checks the writing in the after-class reflective report. For the assessment of students' critical literacy and critical analytical skills, it would be important to assess from the group answers.

- $\quad$ By the end of class, teacher asks every student to make a prediction again of human's future, either in paper or oral presentation. The purpose of the assignment is to check their future tense grammar usage, to examine whether they refine their thoughts, as well as to see what influence this class brings to the students' critical analytical skills.

\section{Phase V: Extension}

- Students are encouraged to watch the whole films if technology affords after class. Further class discussions can happen at next session if students want to share more reflections. At the end of whole course, an essay expressing further thoughts and understanding of the texts is required to submit as a larger, summative assessment.

- Three dystopian novels are recommended for those who are interested in such topics. They are Nineteen Eightyfour by George Orwell (1948), Brave New World by Adouls Huxley (1931) and We by Yevgeny Zamyatin (1921). Moreover, Neil Postman's Amusing Ourselves to Death (1985) is recommended as it discusses how likely the depictions in 1984 and Brave New World will appear in real human futures, thus an extension of the two novels. 